\author{
John KEEFE \\ London Metropolitan University, London \\ Queen's University (Canada), Bader International Study Centre, Hailsham
}

\title{
PLAY(ING) IT AGAIN: RECYCLING AS THEATRES, HISTORIES, MEMORIES
}

Key words: dialectic, empathy, estrangement, habitual, habitus, heteroglossia/hetroglossia, in the beginning, inheritances, lookings, mimesis, nomadic, postproduction, (re)presentation, spectactor/knowing spectator.

\section{A PROLOGUE}

I talk as one returning to Kaunas and Vytautas Magnus University after being a visiting professor here in 1996 and 1997.

I talk as a citizen of the Europe that is both factually and conceptually "Europes": the extended geophysical land mass between the Atlantic and the Urals, the political Europes of unions and communities, the historical and historically impacted Europes, the diasporic and cultural Europes, the imaginary and bordered Europes, the mythical Europa, the diachronic-synchronic overlaps and collisions of these.

I talk as one who is a receiver of the benefits and privileges of such a Western European citizen, but who has not been subject to the traumas of occupation and on-going travails of post-occupation independence, indeed, as one who comes from a nation that turned much of the world into its empire for a short time and is still suffering the symptoms and effects of withdrawal - delusions and false consciousness of a post-imperial power - and is confronting and being confronted by its past as this continually re-arrives.

I talk as one with awareness of the currents and recyclings and returns of those European histories within the long waves of world histories.

\section{AN INTRODUCTION}

In 2008, Knut Ove Arntzen, myself, and colleagues at the Norwegian Theatre Academy launched a project on the concept of "recycling" in the theatre and the academy. ${ }^{1}$ Here, reworking certain dialectical principles, I suggest there are deep human tropes of cultural, social, embodied recycling and the habitual that inform all histories, all actions, all mimesis, and the spectatorial presence.

The argument is predicated on two ideas; the first contesting Baudrillard:

"What the acculturated receive is not culture, but cultural recycling... They get to be "in the know", to "know what's going on"... on a monthly or yearly basis... that low-intensity constraint which is perpetually shifting like fashion and which is the absolute opposite of culture conceived as:

1) an inherited legacy of works, thought and tradition;

2) a continuous dimension of theoretical and critical reflection-critical transcendence and symbolic function."2

Despite - with some justification - his anxiety to condemn mass culture, conspicuous consumption, and the consequent commodification of culture, Baudrillard uses the term "recycling" in a too narrow sense and derogatory tone. Rather, I wish to suggest that our culture is itself both the ephemera and the regarded legacy - an outcome of continuous recycling and concomitant "critical reflection" in perpetuating, mediating and remaking the inherited. 
Secondly, the resonances and implications of "re" itself: from the Latin, a prefix meaning "back" or "again". For my themes here, the questions and consequences arising from our "doing" something with some "thing" - signs, ideas, themes, objects, the body - in our theatres and histories. Too often, this "doing" is merely a re-using or repeating or reiterating (sometimes offering a nominal claim to or patina of "newness"). Or such "doing" may become a re-working, a re-thinking, a re-interrogating or reconstituting that allows some "different" artefact or "thing" or understanding to be seen, to emerge.

But at a deep level and drawing on these practices, the unavoidable recycling of the familiar, the known, the habitual as processes of understanding. To borrow de Certeau's notion of "the nomadic" (1984), those "[...] concrete connections which everchanging, fluid subjects forge between ideological fragments, discourses, and practices".

The question then becomes the more urgent one of what is done with the "re-things"? That is, the position and relationship of the "thing" or "re-thing" to the status quo? Is the "re-doing/re-thinging" a process of perpetuating and re-affirming, or one that is transgressive and a breaking open? Or, more uncomfortably for us, an uneasy and messy combination of these?

To adopt Brecht: does the familiar remain familiar and the strange remain strange or become a critical recycling; the familiar made strange and the strange made familiar, such that we re-look at what we think and feel we know? A dynamic, dialectic relationship resting on the theatre's necessary impulse to recycle mimesis and the spectator's necessary impulse to recycle memories, knowledge and experiences in the reading of those mimetic offerings.

To reposition this invoking of Brecht with its ethical implications, and borrowing from Keynes (the only moral end of economic purpose is the make the world a better place), so the only moral end of theatres and histories is to work toward making the world a better place; or, at least, to a better understanding of this end and how it may be achieved. We must also acknowledge the messy realities, the contrariness of the audiences, the paradoxical presences of theatre
- the fickle and pragmatic demands of fashion, ego, celebrity, business and commercial interests that infect and affect our theatres and historiographies.

But the same principles of conflicts and tensions of ideologies, of ideas, of emotional, cognitive and psychological responses - the agon - remain under all our theatres and histories.

\section{THE KNOWING SPECTATOR (OF THEATRES AND HISTORIES)}

To illuminate this let me offer some provocations towards the problematic; "what is theatre", "what is history"?

"[...] (we are invited) to think of the practice of theatre itself as a constant returning to some very old problems - how to put human beings on stage and have them imitate human beings and their actions". ${ }^{\prime}$

Why is such "putting on stage" a problem? The issue is not the principle of mimesis itself (mimesis: to imitate, to represent, to present imitative figures in a recycling of any and all styles of theatres) but to what end, what purpose the putting on of the imitation? Likewise the practice of theatre is not such imitation in itself but imitation enacted in front of an audience, the spectator. Thus "Spectator- is an onlooker, wholly related to viewing and observation".

Whilst acknowledging the "being" of the spectator, this implicitly (and explicitly elsewhere in the volume) makes the spectator passive, a mere "onlooker". Rather, she/he is always an agent, the engaged participant (Boal's always present "spect-actor") necessary for all theatres to be theatre.

In contrast I would suggest:

"[...] theatre is one group of people playing at being another group of people in front of a separate group of people gathered with expectations and pre-conceptions for the express purpose of presenting or watching, never forgetting what they are doing. Theatre is always estranged and estranging" ${ }^{6}$

In retrospect, I would now add "listening" to the 
spectator's role - that is, watching and listening to what is being presented. Or in semiotic terms, "Theatre is a complex network of interactive, autonomous, and specific sign systems in a dialectical relationship to each other and which together comprise a performance text itself in a dialectical relationship with the spectator-audience"?

These latter formulations capture the category "theatre", the variety and constructed nature of "theatres", the symbiotic, dialectical roles of the actor and spectator in making that construction, the engaged nature of the knowing spectator's role as "spectactor", and the embodied nature of both mimesis and spectating. In this, both the act of making and the act of spectating are processes resting on the axiomatic trope of recycling, the "forgings" that informs and drives our theatres. And likewise histories, where the outcomes are of the actions and forgings of people living in differing circumstances but who are not so very different, one to another. Here, the substance of presentations is not of fictions (an imitation) but of what has happened, however well or ill understood, however clear or blurred. The discovery and understanding of the evidence that has survived by which we seek to interpret and explain the events represented by that evidence.

History becomes a complex study of the recycling and presentation of human activities across space and time. Hence, my bemusement at the confusing of the fictional and the historical, whether of the far or near past, or the present past.

\footnotetext{
"(Alvis Hermanis wrote of) the usurpation of the actor's monopoly (as exercised largely in cinema and theatre) on the production of imitations of reality, by the expansion of television "reality shows" [...] (that) has totally changed the level of credibility which a spectator is ready to accept or - using Stanislavsky terminology - believe".
}

Rather, "reality shows" merely draw on the metaphors of theatre as with all social performance. A strident, vulgar participant on such a show is not imitating but merely exaggerating a reality with a particular level of artifice, of persona. My level of credulity is not challenged by such performance, just as my level of credulity is not deluded by the mimetics of theatre.

“[...] representational theatre is not illusionistic. In illusions we have mistaken beliefs about what we are seeing... We know we are watching people representing something else; we are aware of this, never forget it, and rarely get confused".

I would not restrict this to conventional "representational" theatre. What Rebellato is doing is recasting the phenomenon we call "psychical distance" whereby we know we are watching acting (a mimetic imitation) in the theatre or a performance in a circus, the Big Brother house or on the Trafalgar Square plinth. There is no change in credibility or belief, Stanislavskian or otherwise. As I have said already, we are (re)presenting or watching and listening, never forgetting what we are doing.

The common note here is constructed metaphor: the acting metaphor of the theatrical mimesis as it playfully imitates reality; the performed metaphor of heightened or exaggerated presentation of life itself; of history as forms of metaphor, as we seek to understand that which is past and to which we cannot return except metaphorically or presentationally. In this sense, the past is not only still to change but is also still to come.

Our memories, the histories and mythologies of our narratives, our pasts and presents have the same origins. By this I mean that the genesis of our mimetic fictions and our re-presented histories is the same:

In the beginning...

Once upon a time...

To begin at the beginning...

The ur- or archetypes.

We are confronted by such metaphors in similar ways as spectators and players. We are always willing and knowing suspenders of disbelief. Without such a willing suspension and knowing imagination, there can be no theatre of any kind; it is with such knowing incredulity that I watch the antics of the "reality show-offs", or admire the skills of the aerialist on her trapeze. 
As such, we are agents; always "spect-actors" in that we are always engaged, to varying degrees of commitment and intensity, with the playing, the mimetics, the performing; the recyclings of the worlds being imitated or (re)presented to us.

We have a seductive engagement with the fictions or metaphors of the "other" or alterity: our desire to be the "other", our relationship of difference and opposition to the "other". But also our recognition of our-self in the "other" and hence the imperative to imitate - that is, mimesis and presentation as a compulsion to become or understand the "other". This is the simple, axiomatic truth behind Aristotle's observations that "imitation is natural to man" and that from such mimetics we find our "greatest human pleasure of learning".

Thus are the many layers of "otherness" that we are confronted with: the character as the "other" of the actor, the actor-character as the "other" of the spectator, the stage persona as the "other" of the performer - the dark "other" to be feared. For example, Levinas works from a theory of inter-subjectivity predicated on an interpretation of the self in relation to "lautre"- "autrui", the "other"- "other persons". But because of his commitment to a deistic Other, so Levinas' notion of "other" at all levels remains one of being against, of "unknowing", that which cannot be directly experienced and thus feared.

In contrast to this is the existential "other" of agency, reciprocity and knowing necessary to our being in the world. "Soon after we can see, we are aware that we can also be seen. The eye of the other combines with our own eye to make it fully credible that we are part of the visible world". ${ }^{10}$

Or what we may characterise as "among-others", "[...] that the among-others, like the for-itself and the for-others, is indistinguishable, in its root nature, from the bodily being of persons. The space I live in is the space created, however indirectly, by such bodily being-with". ${ }^{11}$

But such necessary "being-with" is also in dialectical tension with "being against".

When faced with the "other", whether fictional or real, we work with and from our preferences and prejudices, we revert to and re-work the familiar and habitual. That is, we "recycle" what we know to try to understand what we don't know, the new or unfamiliar.

"[...] whenever we receive a visual impression, we react by docketing it, filing it, grouping it in one way or another... the postulate of an unbiased eye demands the impossible". ${ }^{12}$

"A story is not simply a story... It acts to create, sustain, or alter worlds of social relationships". ${ }^{13}$

We make sense of things as agents by "forging" and re-working what we know; we shape our stories and histories as we are shaped by these in mediating processes of recycling.

\section{THE NECESSITY OF RECYCLING}

For Bourriaud, this is "postproduction" - the ontology of objects already informed by other objects, the reconfiguring and recourse to existing works. The principle of postproduction as the before mediating the now, "It's simple, people produce works, and we do what we can with them, we use them for ourselves." ${ }^{14}$

In this way we mitigate the shock of the new by using them for ourselves, by recourse to the known and familiar, recycling these to create routes of access from what we know already. The new is already compromised at the time of it's making and the time of it's reception. Pioneers take their own pasts - their inescapable autobiography - into new routes. Hence the inherent difficulty and paradox of Brecht's attempts to keep us distanced or estranged, as we engage with the transgressive, the normative, and the reaffirming aspects of any and all work as these impact on, and collide with each other.

Why the difficulty and paradox? Because of the roots and routes of such engagements in inheritances and memories, in our embodied and enculturated agency of quite specific kinds. That is, agency as enlightened self-interest within structures of recognised mutuality and reciprocity. The interpretive choices, actions and responses located in the material self that comes from my various inheritances and memories. 
The first are those material, cognitive, psychological and neurological inheritances that emerge as empathy - the "emotion induction sites"15, the work on "mirror neurons" 16 , the inate moral faculty or disposition to not intend harm ${ }^{17}$, or the locating of volition $^{18}$ and emotional processing ${ }^{19}$ in the prefrontal and parietal cortex. The second are those material and enculturated dispositions we may understand as the "habitus" of Mauss ${ }^{20}$ or Bourdieu ${ }^{21}$, the "structures of feelings" of Williams ${ }^{22}$, and the "Hyle" of Husserl ${ }^{23}$. These act together in the recycling of such inheritances in the messy moral-politicalcultural maze and dialectical network of humancentred relations that find mimetic representation in our theatres and re-presentation in our histories. Such inheritances become the memories that inform and deform our reception and understanding of all inherited legacies whether of the theatres or of histories.

To set-up a metaphoric model; re-cycling being not simply a rotating on a fixed, static axis but as a dynamic point or marker on a spiral or elliptical or moving axis. If "re-" is to be read as "back or again" then our memories and inheritances are both fixed and dynamic, working along various axes. In this sense the analogy of the bicycle wheel raised during the panel session is misleading and a misunderstanding; the wheel does not remain in the same place or simply go round and round. Any point on that wheel may be fixed but the revolution round the axle takes the wheel and that point forward. It travels, as we do through history.

Here the paradox is that of the conference itself; we revisit events of recent, changing history whilst this moves inexorably forward, shaping and being (re) shaped by the revisiting.

\section{SOME KINDS OF CONCLUSIONS (IN THE FORM OF EVOCATIONS AND IMAGES)}

A word picture: an elephant chained by the leg in a barred wagon; a child elephant brought to the wagon by a friend; two trunks strain and stretch until the tips touch and entwine. We work through and under the saccharine sentimentality as an animated series of coloured cels touch us, re-memorise us with the pathos and poignancy of the motherchild archetype and the first time we saw the film. We re-live these as we re-watch.

A theatre example: I have seen or know eleven productions of A Midsummer Nights Dream including one of my own. The play remains: the theme and fact of return - from Athens to wood to Athens as same but different; Oberon always tells us "I am invisible and will overhear their conference"; Bottom is "translated" and we enjoy our own particular dreams. But every (post)production is inscribed by its "befores", is one of a series of production palimpsests as it reworks these "befores" (no production is ignorant of its predecessors). Every (post)production is experienced as one of a series of spectatorial palimpsests inscribed and reworked by my knowledge and imagination (no production is ignorant of its predecessors). We are confronted, but also comforted, by a series of mise-en-scène as recycled vanishings and reappearances. Reworking this idea "nomadically", we are practitioners of heteroglossia or "borrowed terms" whereby we use cultural lexicons of words and images already containing or inscribed with previous associations and meanings. ${ }^{24}$

We continually return - dramaturgically - to Hamlet's mirror.

A news item: in July 2009, a treasure hoard of Mercian gold and silver is unearthed in Staffordshire, England. The past - through its objects-as- signifiers - is still arriving, is still changing, reaching us as what we know is both amended and enlarged by such arrivals.

An item of research: in the London Review of Books for 7th January 2010, four books about the events of 1989 were reviewed. What more can be said about the same event(s), except our views and understandings of those events from our perspectives now; the past is still changing.

A personal memory: in 1996, I visited The Ninth Fort in Kaunas. I read the museum information; I walked around the site and its very particular spaces. I could only understand the place and its histories as visceral response, as an "other" opened up and 
mediated by many years of images of camps and prisons, films and theatres about such places that unavoidably inform and allow me routes into what I am seeing and reading and feeling and thinking necessary, remindful memorials to the offensive, to re-cycled amnesias and our propensity to look away, to re-cycled memories themselves.

A question: what is history? Action taken now for the future as informed by the past? Maps of where we have been, mirrors for the now, guides for what happens next? Latitudes and longitudes of the cultural traces that return to us?

In all cases, the present (our inheritances, preferences, phobias, 'isms, lessons, enculturated memories, embodied habits, choices) and the past are a thin blanket, an opaque gauze, a shroud, an aegis laid over each other.

\section{A CODA}

I am inevitably recycling - working nomadically by choice and by default - materials in this paper. I acknowledge these. So, as a closing coda, two further images from my own nomadic "befores":

...a dramaturgical carousel turning very slowly, now recycling the same issues and concerns into a blurred focus every decade. ...on this carousel ghosts and dreams from our histories that haunt our rhetoric, our practices, our anxieties, our desires, our renewals. ${ }^{25}$

These ghosts become the frames and lens that shape our present dramaturgies, mimetics, narratives, and histories. Ghosts that haunt and inform our innovations and explorations, our re-cyclings and re-definings and "re-thingings".

So perhaps the past is always changing, is always here but not yet reached us rather than still to come. Perhaps the carousel is always taking us back to our presents and futures.

\section{AFTER-WORDS AND ACKNOWLEDGEMENTS}

This is a revised and expanded version of the paper given at The Past is Still to Change conference,
Vytautas Magnus University, Kaunas, 2009. As such, it benefits from the papers and discussions running across the days and evenings of the event, for which I express my acknowledgement. The essay purposely retains some of the performative flavour of the paper. In both I endeavour to talk as one who respects the spectrum of histories and experiences represented at the conference, but noting these presentations are themselves manifestations of my theme of "recycling".

\section{Notes}

1 See Camilla Eeg-Tverbakk, Knut Ove Arntzen (eds.), Recycling in Arts, Education and Contemporary Theatre, Halden: Norwegian Theatre Academy, 2009.

2 Jean Baudrillard, The Consumer Society, trans. by Chris Turner, London: Sage, 1998, p. 101.

3 Janice Radway, 'Reception Study: Ethnography and the Problems of Dispersed Audiences and Nomadic Subjects' in: Cultural Studies, Vol. 2, No. 3, 1988, p. 365.

4 Joe Kelleher, "'Human Stuff"' in: Joe Kelleher, Nicholas Ridout (eds.), Contemporary Theatres in Europe, Abingdon: Routledge, 2006, p. 4.

5 Alison Oddey, Christine White, Modes of Spectating, Bristol: Intellect, 2009, p. 12.

6 John Keefe, 'The Spectator is...., Paper given at the European Dramaturgies of the 21st Century conference, J. W. Goethe University, Frankfurt, September 2007.

7 Simon Murray, John Keefe, Physical Theatres: A Critical Introduction, Abingdon: Routledge, 2007, p. 36.

8 Joe Kelleher, 2006, p. 21.

9 Dan Rebellato, 'When We Talk of Horses or, What Do We See When We See a Play' in: Performance Research, Vol. 14, No. 1, 2009, p. 18.

10 John Berger, Ways of Seeing, London: Penguin, 1972, pp. 7, 9.

11 Marjorie Grene, 'Sartre and the Other' in: Proceedings and Addresses of the APA, 45, Newark, DE: American Philosophical Association, 1971-1972, p. 41.

12 Ernst H. Gombrich, Art and Illusion: A Study in the Psychology of Pictorial Representation, Princeton, NJ: Princeton University Press, 1960, pp. 297-298.

13 Kenneth J. Gergen, Realities and Relationships: Soundings in Social Construction, Cambridge, MA: Harvard University Press, 1994, p. 247.

14 Daney cited in Nicolas Bourriad, Postproduction, New York: Lukas \& Sternberg, 2005, p. 13.

15 Antonio Damascio, The Feeling of What Happens, London: Heinemann, 2000.

16 Marco Iacoboni et al., 'Grasping the Intentions of Others With One's Own Mirror Neuron System' in: PLOS Biology, Vol. 3, No. 3, 2005.

17 Marc Hauser, Moral Minds: How Nature Designed Our Universal Sense of Right and Wrong, New York: HarperCollins, 2006. 
18 Patrick Haggard, 'Human Volition: Towards a Neuroscience of Will' in: Nature Reviews, Vol. 9, 2008.

19 Helen Barbas, 'Anatomic Basis of Cognitive-Emotional Interactions in the Primate Prefrontal Cortex' in: $\mathrm{Neu}$ roscience and Biobehavioral Reviews, Vol. 19, No. 3, 1995.

20 Marcel Mauss, Sociology and Psychology, trans. by Ben Brewster, London: Routledge and Kegan Paul, 1979.

21 See Jen Webb, Tony Schirato, Geoff Danaher, Understanding Bourdieu, London: Sage, 2002.

22 Raymond Williams, Drama from Ibsen to Brecht, Harmondsworth: Penguin, 1973; Raymond Williams, Marx- ism and Literature, London: Oxford University Press, 1977.

23 See Natalie Depraz, 'The Husserlian Theory of Intersubjectivity as Alterology' in: Journal of Consciousness Studies, Vol. 8, No. 5-7, 2001.

24 See Mikhail Bakhtin, The Dialogic Imagination, trans. by Caryl Emerson, Michael Holquist, Austin: University of Texas Press, 1981.

25 See John Keefe, 'The Spectator is...., Paper given at the European Dramaturgies of the 21st Century conference, J.W. Goethe University, Frankfurt, September 2007.

\author{
John KEEFE \\ Londono Metropolitan universitetas, Londonas \\ Queen's universiteto (Kanada), Bader tarptautinių studijų centras, Hailšemas
}

\title{
Pakartokime dar kartą: perdirbimas kaip vaidinimas, istorija ir atmintis
}

Reikšminiai žodžiai: dialektika, empatija, atsiribojimas, habitus, heteroglosija / hetroglosija, paveldejjimai, mimezè, nomadiškas, post-produkcija, (re)prezentacija, spekt-aktorius.

Santrauka

2008 metais Knutas Ove Arntzenas, aš ir mūsų kolegos iš Norvegijos teatro akademijos igyvendinome projektą, skirtą perdirbimo (recycling) sąvokai teatriniame ir akademiniame kontekste. Tekste toliau plètojama ši sąvoka, ji siejama su žiūrovo paveldejimų ir žinių perdirbimu teatre ir istorijoje.

Perfrazuojant Brechtą, ar tai, kas pažistama, ir turi likti pažistama, o tai, kas keista - likti keista ar atvirkščiai, tai, kas pažistama, turi tapti keista, o tai, kas keista - pažistama, kad mes būtume priversti iš naujo pažvelgti i tai, ką, atrodytų, jau seniai žinome?

Mano nuomone, kultūrinis perdirbimas yra neatsiejamas nuo mūsų aktyvios veiklos socialinėje ir kultūrinëje aplinkoje, nes čia mes esame paveldètojai, o kartu ir tie, kurie keičia, perkonstruoja, pervadina. Perdirbimas nurodo būdą ir procesus, kurių metu mes - asmeniškai ir kolektyviai - kuriame ir perkuriame pasauli, tvarkome ji ir pertvarkome, ir tokiu būdu jame gyvename ir jị keičiame.

Siekiu parodyti, kad perdirbimas remiasi dinamiškais paveldejjimais, tuo, ką perimame genetine, materialine, socialine ir kultūrine prasme. Siekiu parodyti, kad mūsų teatras ir istorija yra palimpsestas, kur sutinkame tuos, kurie buvo prieš mus, ir tuos, kurie dar ateis, kuriuos žymi neaiškūs šešèliai, vos įžiūrimos šmèklos, prisiminimai ir žinios, kuriuos palieka kiekviena patirtis.

Žiūrovo veiksmo suvokimas yra visuomet įtarpintas to, ką jis matė anksčiau, kuo jis gali remtis, kas jam nuolat primenama. Spektaklio tekstas yra formuojamas, deformuojamas ir reformuojamas. Mes negalime atsikratyti savo pačių vaiduoklių - asmeninių, kultūrinių, socialinių - kai ką nors žiūrime ar patiriame pasaulyje, kuriame gyvename kartu. Manau, šie vaiduokliai yra prizmès ar lęšiai, kurie suteikia pavidalą mūsų nuolat kintančioms praeitims ir dabartims. 